\title{
Implementasi Manajemen Mutu Terpadu (Total QualityManagement) di Sekolah
}

\author{
Desi Ratna Yuli, Rusdinal, Hade Afriansyah \\ Universitas Negeri Padang \\ Indonesia \\ Email : desriratnayuliap@gmail.com
}

\begin{abstract}
Abstrak- Quality is very important in education. We all admit, right now there are indeed problems in the education system. Middle school or college graduates are not ready to meet community needs. This problem affects the community. Anticipating changes that are so fast and the challenges that are getting bigger and more complex, there is no other way for the government to function as an organizer of development in the field of education and educational institutions to seek every means to increase the competitiveness of graduates and other academic products among others, achieved through improving the quality of education.
\end{abstract}

Keywords- management, quality, integrated, education, implementation

\section{Pendahuluan}

Mananjemen Mutu Terpadu pada adasarnya yaitu suatu penilaian yang mendasarkan pada kegiatan pengelolaan organisasi dengan tujuan utama untuk meningkatkan keberhasilan pada tujuan dalam jangka waktu panjang dan tentunya berlanjut secara terus menerus serta meningkatkan kepuasan kepada sipemakai jas atau produk yang dikeluakan. Dalam peningkatan mutunya sendiri, Manajemen Mutu Terpadu ini membutuhkan kerjasama semua pihak yang terkait didalamnya. Sama halnya dengan apa yang terjadi dan berlaku didunia pendidikan. Masyarakatpun salah satunya menuntut mutu lulusan dari lembaga pendidikan yang bersangkutan dengan lulusan yang bermutu tinggi. Hal inilah salah satu pemicu bagaimana mutu dalam dunia pendidikan itu sangat diperhatikan dan ditingkatkan sebaik mungkin.

\section{METODE PENELITIAN}

Artikel ini disusun dengan menggunakan salah satu moetode kajian yaitu kajian literatur, yang dalam penyusunannya mengambil atau meresapi pembahasan yang bersumber dari bahanbahan yang salah satunya merujuk pada sumber yaitu jurnal, buku dan lainnya sehingga dibentuklah hasil pembahasan yang sebaiknya.

Artikel ini juga disusun dalam format yang disesuaikan, terarah dan jelas sebagaimana mestinya, dengan maksud agar lebih mudah dipahami dan dapat menjadi patokan atau 
pedoman bagi para pembaca yang memerlukannya.

\section{KAJIAN TEORI DAN PEMBAHASAN}

\section{A. Konsep Dasar Manajemen Mutu Terpadu}

Manajemen mutu terpadu adalah gabungan dari berbagai fungsi utama suatu perusahaan atau lembaga yang dibangun berdasarkan pada kualitas kerja tim, hasil pengerjaan atau produktivitas dan bagaimana agar kepuasan pelanggan menjadi hal yang harus berjalan dengan baik.

Manajemen mutu terpadu pada awalnya menekankan pada konsep keutamaan yaitu pelayanan serta bagaimana kepuasan pelanggan yang bermutu baik. Dan begitu juga halnya dalam dunia pendidikan saat ini, dalam perkembangannya dalam perkembangan zaman yang terbilang cepat ini, maka dipikirkan bagaimana agar mutu dari pendidikan yang diberikan kepada masyarakat dapat menyesuaikan dengan keadaan dan dapat diperhitungkan alumni dalam menghadapi dunia kerja setelah ia berhasil menamatkan pendidikannya nanti.

Jadi pada dasarnya dapat disimpulkan bahwa kepuasan yang dirasakan oleh pelanggan akan tergantung bagaimana kualitas pelayanan yang didapatkannya dari suatu lembaga atau perusahaan tertentu.hal ini juga tak menuntut kemungkinan pada apa yang diharapkan oleh pelanggan sendiri, jika ia merasa membutuhkan atas apa yang diberikan oleh suatu perusahaan

\section{B. Manajemen Mutu Terpadu Dalam Pendidikan}

Manajemen Mutu Terpadu Pendidikan dalam perealisasiannya mencakup akan dua pokok penting yanga mana dua pokok penting tersebut adalah apa dan bagaimana menjalankan manajemen mutu pendidikan dengan semestinya.

Manajemen Mutu Terpadu Pendidikan dalam kerjakan berfokus terhada bagaimana upaya dalam melaksanakan peningkatan dan penyempurnaan mutu pendidikan. Yang mana dengan hal itu maka dalam lembaga pendidikan setiap orang yang tergabung didalamnya memiliki status, posisi, pekerjaannya masing-masing yang mana hal ini tak bisa digantikan atau dipindah tangankan pada orang sembarangan.

Manajemen mutu terpadu pendidikan dijadikan sebagai sumber untuk dilakukannya perubahan yang teradi secara kontiniu dan hal ini hanya bisa dilakukan dengan bantuan seseorang tentunya. Yang mana dalam pelaksanaannya kepala sekolah bertugas untuk memberikan keyakinan dan mendapatkan kepercayaan dari warga agar dapat menerapkan dan menilai bagaimana peningkatan mutu yang telah dilaksanakan dilembaga pendidikan tersebut. 


\section{Pembahasan}

Manjemen Mutu Terpadu Pendiikan dalam pelaksanaannya sangat membutuhkan tenaga kerja atau tim kerja yang benar-benar fokus dan berniat untuk memulai peerapan mutu yang baik dan seharusnya pada lembaga pendidikan itu sendiri terlebih dahulu. Bagaimana aspek yang baik dalam pelaksanaan proses pendidikan, apasaja yang dirasa perlu dilengkapi agar pendidikan dapat bermutu baik dan seterusnya harus dengan dipikirkan dengan matang disini.

Dalam hal itu kepala sekolah beserta wakilnya harus bisa berperan untuk mengupayakan pendidikan yang semsetikan bagi siswanya serta para staf yang berada dibawah naungannya. Bagaimana kepala sekolah. Salah satu bentuk peran kepala sekolah ini yaitu dalam hal mengubah tata cara kepemimpinan atau manajemen sekolah yang tradisional agar dapat sejajar dengan perkembangan yang terjadi saat ini.

Dalam pelaksanaan perubahan pada perkembangan mutu yang dilakukan oleh lembaga pendidikan ini tidak bisa dikategorikan pada perubahan yang dapat dilakukan secara instan. Butu waktu yang cukup lama untuk merubah salah satu aspek yang sangat penting pada hal ini yang mana aspek tersebut adalah aspek budaya. Karna hal itu dalam pengembangannya harus dilakukan dengan sungguh-sungguh dan harus berhati-hati karna hal ini juga tak luput dati tantangan yang akan terjadi.

Menurut Erra (Erra Yusmina, 2014)Sekolah dapat diartikan sebagai lembaga yang dalam pelaksanaannya meliputi proses belajar mengajar yang anak-anak didalamnya diatur berdasarkan tingkatan atas kemampuan yang diperoleh dan ditetapkan untuk setiap jenjang pendidikannya.

\section{KESIMPULAN}

MMTP ialah gabungan dari berbagai fungsi utama suatu perusahaan atau lembaga yang dibangun berdasarkan pada kualitas kerja tim, hasil pengerjaan atau produktivitas dan bagaimana agar kepuasan pelanggan menjadi hal yang harus berjalan dengan baik. Manajemen mutu terpadu pendidikan dijadikan sebagai sumber untuk dilakukannya perubahan yang teradi secara kontiniu dan hal ini hanya bisa dilakukan dengan bantuan seseorang tentunya. Yang mana dalam pelaksanaannya kepala sekolah bertugas untuk memberikan keyakinan dan mendapatkan kepercayaan dari warga agar dapat menerapkan dan menilai bagaimana peningkatan mutu yang telah dilaksanakan dilembaga pendidikan tersebut.

\section{Daftar Pustaka}

Afriansyah, H. (2019). MANAJEMEN MUTUTERPADU.1.http://doc.org/10. 17605/OSF.IO/NRXHS 
Agus Suwignyo, 2008. Pendidikan Tinggi \& Goncangan Perubahan. Yogyakarta: Pustaka Pelajar

Ahmad Tafsir, 2011. Ilmu Pendidikan Dalam Perspektif Islam. Bandung: PT. Remaja Rosdakarya

Sutrisno \& Muhyidin Albarobis, 2012. Pendidikan Islam Berbasis Problem Sosial. Jogjakarta: Ar-Ruzz Media

Husaini Usman, 2014. Manajemen Teori Praktik dan Riset Pendidikan. Jakarta: PT Bumi Aksara

Oemar Hamalik, 2010. Manajemen Pengembangan Kurikulum. Bandung: PT Remaja Rosdakarya.

Rusdinal, (2009). BUDAYA ORGANISASI PASCA PEMBANGUNAN DENGAN DUKUNGAN MANAJEMEN BERBASIS SEKOLAH. Pedagogi, 33(2). Retrived from http://journal.um.ac.id/index.php /ilmupendidikan/articlc/view/1200

Erra Yusmina. (2014). IMPLEMENTASI

MANAJEMEN MUTU TERPADU DALAM PENINGKATAN KINERJA SEKOLAH PADA SMK NEGERI 1 BANDA ACEH.

Pedadogi, 4(2), 11. Retrieved from http://www.jurnal.unsyiah.ac.id/JAP/article/v iew/2520/2367 